\title{
Pamidronate therapy for hypercalcemia and congenital mesoblastic nephroma: a case report
}

\author{
Fahimeh Soheilipour ${ }^{1}$, Mahmood Ashrafi Amineh², Mahin Hashemipour ${ }^{1}$, \\ Ali Asghar Salahi Kojoor ${ }^{2}$ and Amir Hosein Davarpanah Jazi*3
}

\author{
Address: ${ }^{1}$ Department of Pediatric Endocrinology, Isfahan University of Medical Sciences, Isfahan, Iran, ${ }^{2}$ Department of Pediatric Surgery, Isfahan \\ University of Medical Sciences, Isfahan, Iran and ${ }^{3}$ Medical Education Research Center, Isfahan University of Medical Sciences, Isfahan, Iran \\ Email: Fahimeh Soheilipour - soheilipour@resident.mui.ac.ir; Mahmood Ashrafi Amineh - ashrafi@med.mui.ac.ir; \\ Mahin Hashemipour - hashemipour@med.mui.ac.ir; Ali Asghar Salahi Kojoor - salahi@resident.mui.ac.ir; Amir Hosein Davarpanah \\ Jazi* - davarpanah@edc.mui.ac.ir \\ * Corresponding author
}

Published: 12 December 2009

Cases Journal 2009, 2:9315 doi:10.1I86/1757-1626-2-93I5

This article is available from: http://www.casesjournal.com/content/2/I/9315

(c) 2009 Soheilipour et al; licensee BioMed Central Ltd.

This is an Open Access article distributed under the terms of the Creative Commons Attribution License (http://creativecommons.org/licenses/by/2.0), which permits unrestricted use, distribution, and reproduction in any medium, provided the original work is properly cited.
Received: 20 October 2009

Accepted: 12 December 2009

\begin{abstract}
Hypercalcemia can causes life threatening complications. We report an infant with severe hypercalcemia due to congenital mesoblastic nephroma. Hypercalcemia was corrected before nephrectomy by pamidronate. According to our knowledge this is a rare case with severe neoplasm induced hypercalcemia among neonates who treated by bisphosphonates. The aim of this report is to define new approach to neoplasm induced neonatal hypercalcemia.
\end{abstract}

\section{Introduction}

In infants, hypercalcemia is a rare but serious condition. Some causes of hypercalcemia in neonatal period include severe primary hyperparathyroidism, homozygous familial hypocalciuric hypercalcemia, idiopathic infantile hypercalcemia, William's syndrome, iatrogenic administration of calcium (generally intravenously), vitamin A or D intoxication and subcutaneous fat necrosis or as a form of paraneoplastic syndromes. They can be complicated by potentially life-threatening hypercalcemia which should be investigated and treated without delay $[1,2]$.

Life-threatening hypercalcemia is rare in infants and young children. Pharmacological treatment of severe hypercalcemia is complicated by lack of experience with some effective medications such as bisphosphonates in newborns.
Congenital mesoblastic nephroma is the most common renal tumor in neonatal and early infantile period. It can be associated with paraneoplastic syndromes, such as hypertension and hypercalcemia [1].

We report a 9 day old newborn infant with history of polyhydramnios, a right-sided renal mass duo to mesoblastic nephroma, hypercalcemia and hypertension which was treated with a bisphosphonate, pamidronate, to stabilize life-threatening hypercalcemia before nephrectomy.

\section{Case description}

A 9-day old male newborn infant was admitted in our hospital with history of poor feeding, vomiting, decreased tonicity, lethargy, and dehydration since two days before. He was the second-born child of non consanguineous parents. His mother had history of polyhydramnios. He 
was the product of caesarian section because of polyhydramnios. Birth weight was 3700 g, Apgar scores were normal and he was discharged at the first day of age.

On admission findings were as follows: heart rate 143/ $\mathrm{min}$, respiratory rate $52 / \mathrm{min}$, blood pressure (BP) $140 /$ $110 \mathrm{mmHg}$, weight $2.30 \mathrm{~kg}$. He had lost $1400 \mathrm{~g}$ since birth and had a mild degree of hypotonia and hyporeflexia.

Physical examination revealed a large right-sided abdominal mass with regular margins (Fig 1). Ultrasound examination showed a large echogenic and heterogeneous mass composed cystic areas that was $85 \times 65$ mm confirmed.

Initial biochemical studies revealed serum calcium of 17 $\mathrm{mg} / \mathrm{dl}$ (reference range $8.2-10.5 \mathrm{mg} / \mathrm{dl}$ ). He had persistent hypercalcemia (serum calcium $>15 \mathrm{mg} / \mathrm{dl}$ ) for more than 6 hours before medical therapy. Other laboratory tests were in normal ranges and serum Phosphorus and magnesium were $3.8 \mathrm{mg} / \mathrm{dl}$ and $2 \mathrm{mg} / \mathrm{dl}$ respectively.

At first visit we tried normal saline and furosemide but no obvious response was seen. Then the patient received two intravenous pamidronate $(1.5 \mathrm{mg} / \mathrm{kg})$ for 2 days. Pamidronate infused in 25 milliliter of $5 \%$ dextrose saline solution over 4 hours. His serum calcium level decreased significantly, and about 18 hours later, his total calcium level normalized and his symptoms recovered except abdominal mass. Because our patient was hypertensive, we prescribed nifedipine also. Unfortunately we do not have the levels of serum PTH and specific markers of bone turnover because were not measured.

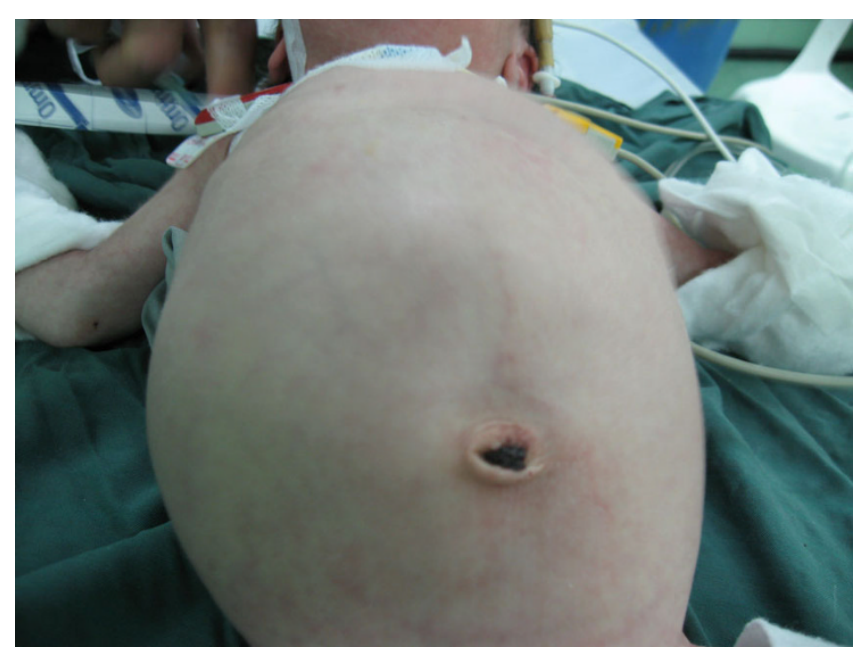

Figure I

The figure shows the huge abdominal mass dominant in right side.
After stabilization of hypercalcemia, successful right nephrectomy was performed.

Histological evaluation of revealed a well circumscribed, $11 \times 10 \times 8 \mathrm{~cm}$, round shape, smooth yellow mass in the upper pole of the right kidney (Fig 2). On the microscopic examination the lesion displayed bundles of spindle shaped stromal cells with occasional entrapped normal renal tubular and glomerular cell, findings that consistent with diagnosis of mesoblastic nephroma (Fig 3). After operation serum calcium level doesn't increase again. The normal blood pressure achieved about 16 hours after operation.

\section{Discussion}

We described a neonate with severe paraneoplastic hypercalcemia. Hypercalcemia in this situations, have been reported to be caused by the tumor secretion of PTH, РTHrelated peptide [2], prostaglandin E2 [3] and glucagonlike peptides [4]. When the total calcium concentration is $14 \mathrm{mg} / \mathrm{dL}$, emergency intervention is necessary because of life-threatening adverse effects of hypercalcemia on heart, brain, kidney, and gastrointestinal function. Hypercalcemia that is an uncommon complication of childhood cancers, has been reported in association with childhood renal tumors in $1.2 \%$ of cases, compared with $0.7 \%$ among childhood solid tumors in general $[5,6]$.

Despite the response to pharmacological therapy with hydration and furosemide diuresis, in many times is inadequate and transient, pharmacological treatment of hypercalcemia with medications such as bisphosphonates is complicated by lack of experience in newborns. We use pamidronate, to stabilize hypercalcemia, prior to

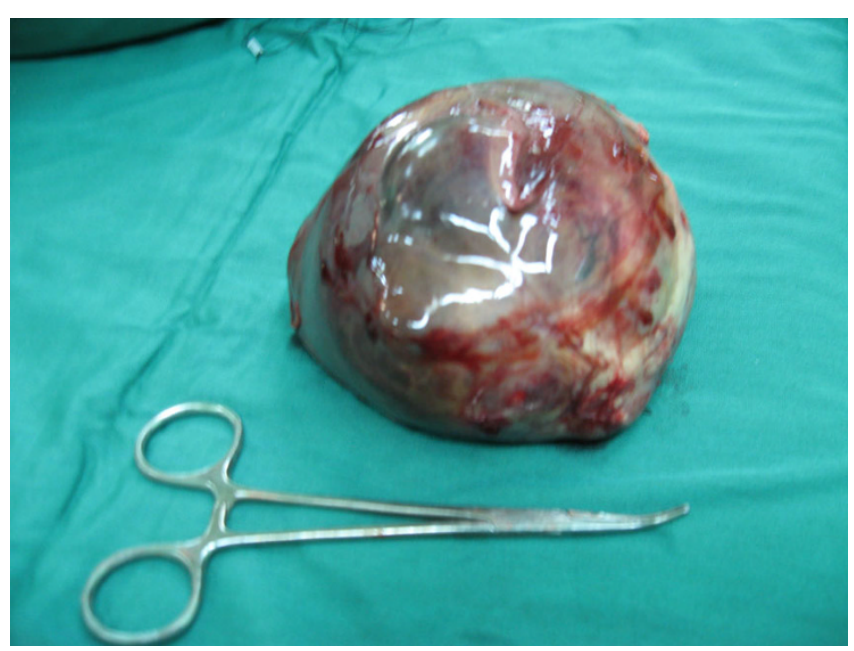

Figure 2

Gross picture of removed mass. 


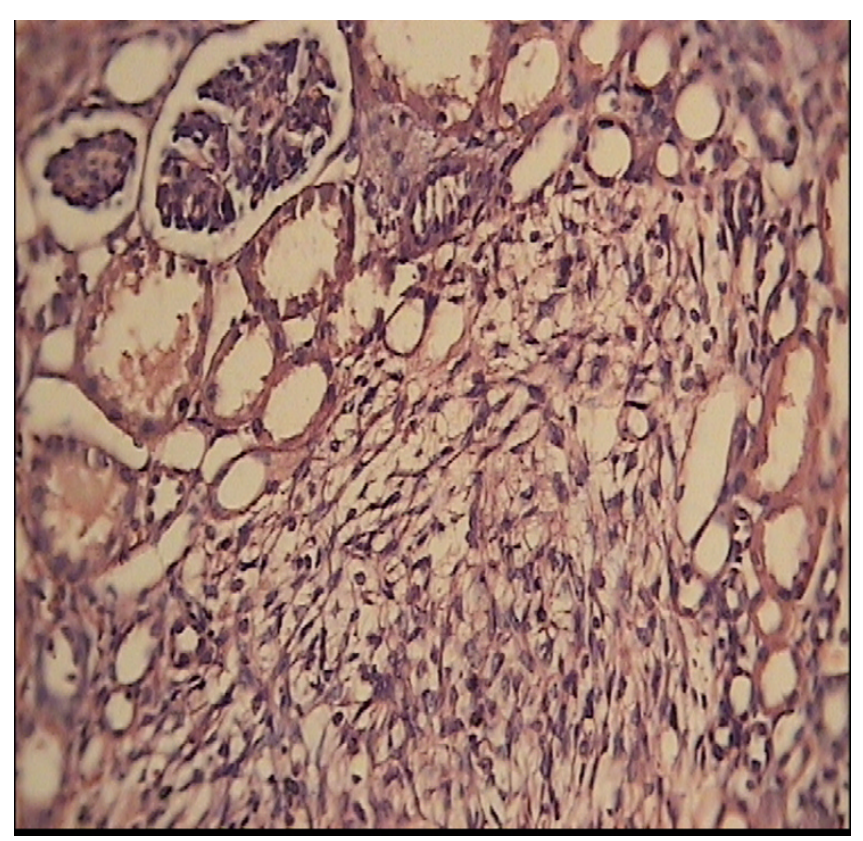

Figure 3

Hematoxiline and eosin staining of the tumor specimen showed bundles of spindle shaped stromal cells with occasional entrapped normal renal tubular and glomerular cell. (1000x).

nephrectomy. The serum calcium was successfully decreased without any complications.

Fox et al for the first time described the use of pamidronate to control marked hypercalcemia in neonatal hyperparathyroidism that resulted from an inactivating mutation of the calcium-sensing receptor. They treated their neonate, with intravenous pamidronate $(20 \mathrm{mg} /$ $\mathrm{m}^{2}$ ). Six doses of 20 to $30 \mathrm{mg} / \mathrm{m}^{2}$ were given over the next 6 weeks with the aim of performing parathyroidectomy once it was technically feasible and she was clinically stable [7]. Although total dose of pamidronate in this case was higher than our patients but each prescribed pamidronate doses was lower. It may due to lower calcium level in their patient.

In another study by Alos et al, Four newborns presented with subcutaneous fat necrosis complicated by severe hypercalcemia were reported. Despite traditional treatment, calcium levels persistently remained high. By using 3-4 doses of pamidronate $(0.25-0.50 \mathrm{mg} / \mathrm{kg} /$ dose $)$ calcium levels decreased within 48-96 h [8].

Bryowsky et al reported a 17-day-old premature infant who received $0.7 \mathrm{mg} / \mathrm{kg}$ of pamidronate for treatment of hypercalcemia due to parenteral nutrition. His serum calcium concentration returned to normal without any adverse reaction. They also propose clinical trials in pediatric patients are necessary to determine how best to use bisphosphonates in these patient populations [9].

Despite a few studies like these, there are a few controlled studies that have been performed on the use of pamidronate, to stabilize life-threatening hypercalcemia among newborns; therefore, dosing guidelines are not available. Some mentions doses for intravenous pamidronate administration in newborn studies for treatment of hypercalcemia resulting from different causes have varied from 0.35 to $1.2 \mathrm{mg} / \mathrm{kg}$ per dose or $0.25-0.50 \mathrm{mg} / \mathrm{kg} /$ dose [8]. In our case higher dose of tolerable pamidronate was administered and therefore rapid response to treatment was achieved in such critical emergent setting.

\section{Conclusion}

Intravenous pamidronate appears to be a safe and effective treatment for severe hypercalcemia among neonates and infants with life-threatening paraneoplastic hypercalcemia. This could stabilize the patients before surgery especially those who do not respond adequately to traditional treatments or when urgent surgery is impassible.

\section{Consent}

Written informed consent was obtained from the patient for publication of this case report and accompanying images. A copy of the written consent is available for review by the Editor-in-Chief of this journal.

\section{Competing interests}

The authors declare that they have no competing interests.

\section{Authors' contributions}

FS and $\mathrm{MH}$ analyzed and interpreted the patient data as well as make the proper diagnosis. MAA and AASK performed the surgical procedure. FS and AHDJ were the major contributors in writing the manuscript. All authors read and approved the final manuscript.

\section{References}

I. Glick RD, Hicks MJ, Nuchtern JG, Wesson DE, Olutoye OO, Cass DL: Renal tumors in infants less than 6 months of age. J Pediatr Surg 2004, 39(4):522-5.

2. Rousseau-Merck MF, de Keyzer Y, Bourdeau A, Cournot G, Mercier F, Nezelof C: PTH mRNA transcription analysis in infantile tumors associated with hypercalcemia. Cancer 1988, 62(2):303-8.

3. Jayabose S, Iqbal K, Newman L, San Filippo JA, Davidian MM, Noto R, et al.: Hypercalcemia in childhood renal tumors. Cancer 1988, 61 (4):788-9|.

4. Rousseau-Merck MF, Mercier F, Bataille D, Nezelof C: Ectopic G-29 and G-37 glucagon secretion by hypercalcemic infantile renal tumors. Peptides 1986, 7(Suppl I):249-52.

5. Daskas N, Argyropoulou M, Pavlou M, Andronikou S: Congenital mesoblastic nephroma associated with polyhydramnios and hypercalcemia. Pediatr Nephrol 2002, I7(3): 187-9.

6. Fung TY, Fung YM, Ng PC, Yeung CK, Chang MZ: Polyhydramnios and hypercalcemia associated with congenital mesoblastic nephroma: case report and a new appraisal. Obstet Gynecol 1995, 85(5 Pt 2):815-7. 
7. Fox L, Sadowsky J, Pringle KP, Kidd A, Murdoch J, Cole DE, et al.: Neonatal hyperparathyroidism and pamidronate therapy in an extremely premature infant. Pediatrics 2007, | 20(5):e|350-el354.

8. Alos N, Eugene D, Fillion M, Powell J, Kokta V, Chabot G: Pamidronate: Treatment for severe hypercalcemia in neonatal subcutaneous fat necrosis. Horm Res 2006, 65(6):289-94.

9. Bryowsky JJ, Bugnitz MC, Hak EB: Pamidronate treatment for hypercalcemia in an infant receiving parenteral nutrition. Pharmacotherapy 2004, 24(7):939-44.

Publish with Bio Med Central and every scientist can read your work free of charge

"BioMed Central will be the most significant development for disseminating the results of biomedical research in our lifetime. "

Sir Paul Nurse, Cancer Research UK

Your research papers will be:

- available free of charge to the entire biomedical community

- peer reviewed and published immediately upon acceptance

- cited in PubMed and archived on PubMed Central

- yours - you keep the copyright

Submit your manuscript here:

http://www.biomedcentral.com/info/publishing_adv.asp 